Benito Arruñada

Pompeu Fabra University

\title{
Pitfalls to Avoid when Measuring Institutions: Is Doing Business Damaging Business?*
}

\author{
Journal of Comparative Economics, 2007, 35(4), 729-47.
}

\begin{abstract}
Over recent years, both governments and international aid organizations have been devoting large amounts of resources to "simplifying" the procedures for setting up and formalizing firms. Many of these actions have focused on reducing the initial costs of setting up the firm, disregarding the more important role of business registers as a source of reliable information for judges, government departments and, above all, other firms. This reliable information is essential for reducing transaction costs in future dealings with all sorts of economic agents, both public and private. The priorities of reform policies should therefore be thoroughly reviewed, stressing the value of the legal institutions rather than trivializing them as is often the case.
\end{abstract}

JEL Classification: K22, K23, L59, O17.

Keywords: starting business, doing business, informal economy, company registers.

\footnotetext{
* Department of Economics and Business. Universitat Pompeu Fabra. Trias Fargas, 25. 08005-Barcelona (Spain). Email: benito.arrunada@upf.edu. I thank Veneta Andonova, Andrés Catalán Cárdenas, Wade Channell, Luis Fernández del Pozo, Paul Holden, Francisco Marcos, Richard E. Messick, Joaquín Rodríguez Hernández and Xosé H. Vázquez and acknowledge comments by this journal's editor and reviewers, as well as workshop participants at the Ronald Coase Institute, Pompeu Fabra University, the $14^{\text {th }}$ CINDER Conference and the French Conseil d'État. Usual disclaimers apply. This study received financial support from the Spanish Ministry of Education and Science, through grant SEJ2005-03871/ECON and the European Commission through the Integrated Project CIT3-513420.
} 


\section{Introduction}

There have been many recent initiatives to simplify procedures for starting-up businesses, especially since the World Bank has been publishing its annual Doing Business reports. ${ }^{1}$ These are based on a survey method drawn up by Djankov et al. (2002) and inspired by the ideas of Hernando de Soto $(1986,2000)$ and estimate, amongst many other indicators on obstacles to business activity, how many procedures are needed and the costs incurred in starting-up a business in each of the 175 countries that currently participate in the survey.

In essence, Djankov et al. argue that politicians and bureaucrats regulate "entry" (or rather, the formalization ${ }^{2}$ ) of firms with the sole aim of rent-seeking, without taking into account the fact that such formalization also generates services that are of use for firms themselves and for the public administration. It is true that an element of rent-seeking does exist in formalization processes. However, formalization also entails benefits, and omission of the analysis and measurement of such benefits has serious consequences for institutional and economic development. A narrow focus on rent-seeking implicitly assumes that the social benefits of formalization do not differ across different formalization institutions, and the recipe for simplification ends up doing little more than cutting back formalities while disregarding the value of the services offered. In fact, if the rent-seeking hypothesis were confirmed, any type of mandatory procedure should be suppressed. So, if the World Bank were completely consistent with regard to the theory on which Doing Business is based, it should not just simplify but eliminate all mandatory procedures.

As shown below, things are not that simple, so not even the World Bank is taking its analysis to its ultimate consequences. This is because not only do reformers come up against vested interests but also at least some of the mandatory procedures provide socially useful services. In practice, what often happens is that, instead of eliminating procedures, these are just compressed and speeded up. To achieve these meager results, governments and development aid organizations invest in information technology and often create new bureaucratic structures, even introducing new procedures and new legal figures, thus adding to an already complex system. ${ }^{3}$ But such compression of procedures does not improve the quality of the information entering or leaving the

\footnotetext{
${ }^{1}$ World Bank (2003-2007). See also the Doing Business web site to consult and download data on each country (http://www.doingbusiness.org/, visited 21 February 2007). The World Bank efforts in this field have taken place in parallel with those of other international organizations such as the $\operatorname{OECD~}(2003,2006)$. Also, see World Bank (2003, pp. 1-15) for a description of another eight international indicators of institutional environment quality.

2 It is significant that the original work by Djankov et al. (2002) was entitled "Entry regulation”. Economists usually talk about how costly it is to enter a market or about "entry barriers" when, for reasons associated with the market's competitive structure, such as the presence of a monopolist, it is difficult to compete in it. The title suggests that the costs of formalization represent an additional barrier to entry and, by doing so, emphasizes the costs of formalization and suggests they should be reduced. This in itself is not bad but use of this simile leads to omission of the fact that, by incurring certain formalization costs today, transaction costs in the future will be reduced whereas conventional entry barriers do not generate this kind of positive effect.
}

${ }^{3}$ See the example of the failed introduction in 2003 of the Sociedad Limitada Nueva Empresa (SLNE), a new type of company, in Spain, described in Arruñada (2007b) and awkwardly considered a success by the World Bank (2004, pp. 17-18). 
public formalization registers, and sometimes even worsens it. In spite of their cost, these policies do not enhance the value of formalization, which is especially necessary in less developed countries, many of which do not have effective formalization institutions. The emphasis on the reduction of explicit costs, disregarding the value of institutions, is therefore especially harmful for development.

The rest of the article is structured as follows. After describing in Section 2 the current fashion for simplification policies, sections 3 to 6 identify their key failures. Section 3 argues that focusing on rent seeking risks disregarding the - often more important - value of services provided by formalization institutions. Section 4 points out that consideration of only the costs of compulsory procedures neglects the substitutions that take place between both compulsory and voluntary procedures at the time of business formalization and between initial and future procedures. Section 5 shows how international comparisons of average costs disregard the role of economies of scale and predispose policymakers to omit adapting the reforms to the demand and supply conditions in each country. Finally, Section 6 describes the common mistakes incurred when estimating the costs of formalization, taking as an example the case of the US in Doing Business. Section 7 concludes by explicitly summarizing the alternative methodology which is implicit in these criticisms: one that would pay attention not only to the compulsory initial costs of formalization but also to the full array of transaction costs and, in particular, the value of services provided by formalization institutions. Such an alternative would gear policy toward efficiency instead of focusing on partial estimates of initial costs.

\section{The fashion for simplification}

Guidelines for policy and best practices usually emerge slowly. In the case of simplification policies, especially in the area of business start-up, however, powerful forces have speeded up the adoption of policy guidelines which I will argue are deeply misguided. First, a pilot study was carried out, collecting data and comparing some hypotheses. A scientific article was then published, and policy was also proposed on the basis of these preliminary results. Since then, the World Bank has continued collecting data of the same type and publishing them annually, in a project led by some of the authors of the pilot study. The fact that an institution as relevant as the World Bank is involved in the project covers up its defects and vouches for its conclusions which, in a normal situation, would be taken as preliminary, having a limited effect on policy. There is therefore considerable risk that preliminary conclusions will be taken as final and used for establishing wrong "best practice" standards and for taking mistaken decisions in institutional reform. ${ }^{4}$

This risk has already started to make its presence felt. In spite of the negative results of these recipes for simplification, they are having a considerable impact on institutional reform in many countries, mainly with respect to the regulations for starting up a business, the most popular reform (World Bank, 2006, p. 3). And it is not only the World Bank itself that has been using the

\footnotetext{
4 The negative impact resulting from such adoption of defective policies could be huge. The direct cost of drafting the Doing Business reports seems to be low, however. The Economist quoted Doing Business sources stating that the annual cost was two million dollars (“Unblocking Business,” 15 September 2005).
} 
Doing Business data internally for imposing conditions on its debtors. The Millennium Challenge Account, a mechanism devised by the United States to channel aid to developing countries, also uses these and similar markers to identify the countries that most deserve development aid, which is then given with few strings attached. ${ }^{5}$ Similarly, in 2003 the International Development Association donors set targets to reduce the cost and time involved in starting-up a business as a condition for receiving further funding (World Bank, 2006, p. 3). ${ }^{6}$ The European Union has been following suit since 2000 when it drew up the European Charter for Small Enterprises. ${ }^{7}$ In a more recent twist, since the end of 2006, Doing Business has been giving publicity not only to the countries with the best ratings but also to those obtaining the lowest ratings. Many countries are now redesigning their policies with the express aim of achieving higher scores in rankings such as that of Doing Business. Not only are they carrying out the usual window-dressing with regard to the functioning of their institutions but they are racing to restructure their institutional reforms to include simplification of business formalization. ${ }^{8}$ In turn, Doing Business often praises reforms in

\footnotetext{
5 The Millennium Account which, from the start, has included among its criteria the time for starting up a business is very satisfied with its effectiveness, and shows great faith in its figures. "We are currently using the Days to Start a Business indicator and have seen significant improvements in the median score for low income countries: from 62 days in 2002 to 45 days in 2005. According to the World Bank Group, 80\% of the business start-up reforms that they have observed are directly attributable to the incentive effect of the MCA” (MCC, 2005, p. 2).
}

6 Doing Business 2005 already proclaimed that "the main success story is that business start-up is now easier for borrowers from the International Development Association (IDA) - encouraged by performance targets set in the 13th IDA funding round and by the Millennium Challenge Account” (World Bank, 2004, pp. 1-2).

7 See http://europa.eu.int/comm/enterprise/enterprise_policy/charter/index en.htm (visited 4 November 2005).

8 The emphasis on improving the score can also be seen on the Doing Business website and in the news from the World Bank, which encourages governments to "simulate reforms: How would a country's ranking change if it reformed? See the impact of reforms by using the ranking simulator (Excel, 186KB) to change indicator values" (http://www.doingbusiness.org/documents/Ease_of_DB_2007.xls, visited 24 August 2007). It is revealing to note how the Bank reports on the missions of the Doing Business management team: "In response to the request of the Government of Azerbaijan to support its efforts in improving the business environment and Azerbaijan ratings in the Doing Business 2007 Report, ... a mission headed by Mr. Simeon Djankov, the main author of the Doing Business Report, visited Azerbaijan from January 29 through February 2, 2007. The main purpose of the joint mission organized by the WB, IFC, FIAS and Doing Business Group was to discuss with the Ministry of Economic Development and other key government counterparts possible ways of improving the country's international ratings on business and investment climate” ("World Bank Group Mission On Doing Business 2007 Report,” Baku, 2 February, 2007, emphasis added, http://web.worldbank.org/WBSITE/EXTERNAL/NEWS/0,,contentMDK:21205557 menuPK:51062078 pagePK:34 370 piPK:34424 theSitePK:4607,00.html, visited 28 March 2007). 
this direction without taking into account the frequently poor results; ${ }^{9}$ and the actual Doing Business team regularly serve as advisors to governments. ${ }^{10}$

The trend is reinforced by the media transmitting a false idea of simplicity and low cost, backed up by the sports-league format used to present results. ${ }^{11}$ Take, for example, an editorial in the Financial Times describing business formalization reforms as "simple administrative steps". ${ }^{2}$ And the Financial Times is not alone in this uncritical attitude nor in stating that reforms in this area are easy. ${ }^{13}$ Unfortunately, things are not so simple. On the one hand, the procedures that are easy to eliminate are neither numerous nor very important. On the other, in practice, reforms are far from being simple and, in many cases, rather than simplifying they introduce new procedures and create new organizations.

Apart from the support of international agencies and the media, the fact that such simplistic institutional reform proposals should have achieved such widespread support stems from other factors. Firstly, there are marked informational asymmetries in the costs and benefits of the reforms. Secondly, they serve the private rent-seeking interests of many agents.

${ }^{9}$ For example, as a result of the reforms financed by the US development agency (USAID) and according to Doing Business 2007, Afghanistan has reached position 17 in the world for ease of setting up a business for which, according to this report, only three formalities are needed, taking about eight days (online data, 17 May 2007). However, Afghan entrepreneurs tell a different story. Although the actual company incorporation can be done fast, up to 18 months are needed to obtain the licenses required to start operating. The reforms have just postponed the most important restrictions until after the legal incorporation. (I thank Wade Channel for this information). Along the same lines, Doing Business 2007 named El Salvador as one of the countries that had adopted reforms in this area. Also, Doing Business 2005 praised the efforts of the Spanish reforms and the introduction of the SLNE (World Bank, 2004, pp. 17-18), as well as those of Colombia (p. 20). However, as shown in Arruñada (in press), neither of these reforms can be considered positive.

10 See the Dutch case in Ladegaard, Djankov and McLiesh (2007) and the reference to Azerbaijan in n. 9.

11 “'It is like sports,' says Simeon Djankov, an author of the report, “If you keep score, no one wants to lose.' In the past, the Bank has been coy about publishing its full league table, for fear of offending the governments at the bottom. But this year there is nowhere for the losers ... to hide. Mr Djankov reckons that 21 different reforms over the past two years were inspired by the 'Doing Business' audit” (“Unblocking Business,” The Economist, 15 September 2005).

12 The full text reads as follows: "This year, in a welcome break with tradition, two-thirds of African countries have adopted some sort of helpful reform. And why not? International development may be full of difficult choices and expensive projects, but these reforms are often simple administrative procedures: the stroke of a minister's pen or a low-cost modernisation of the industry ministry's website, and big barriers to doing business can be swiftly demolished. The mere embarrassment of being caught between the report's cold facts and its brusque language is often enough to push bureaucrats into doing something: one can just imagine ministers banging the table and demanding improvements. When it became clear, for instance, that businesses in Lagos typically had to wait six months for the approval of the governor before buying business premises, delays were quickly cut by 70 per cent. Several countries are now explicitly aiming to move up the Doing Business rankings. This is important because for some entrepreneurs mere red tape is causing greater difficulties than costlier problems such as poor roads or unreliable electricity. Infrastructure also needs improving, but that is often hard. There is little excuse for slow progress when cutting red tape can be such a simple affair” ("Undoing Business," Financial Times, 6 September, 2006).

13 See another example of unfounded optimism in O’Grady (2006). The Economist has repeatedly expressed similar optimism, describing reforms as "audits" (n. 11). In an initial editorial on this "excellent new study" it stated, "the report is a mine of useful as well as disturbing information, and something of a handbook for how to put things right", and "reforming or repealing bad regulations is easier than you think" (respectively: "Regulatory Reform: Breaking Poverty’s Chains” and "Measure First, then Cut," 9 September 2004). 
With regard to the information asymmetries, entrepreneurs are much more aware of the costs of procedures to gain access to the system than of the private benefits afforded by the system in terms of lower transactions costs in their dealings with other firms. Moreover, the direct costs of formalization are easier to measure than the value of the services provided by a good formalization system. It is therefore logical for governments to focus on reducing the most obvious costs as this keeps entrepreneurs happy and the government can advertise its success with measurable data. Little attention is paid to the fact that, amongst other omissions, reforms have not improved judges' confidence in registration information, such confidence being needed to reduce total business transaction costs.

Simplification also benefits from the apparent modernity of using information technology tools and the apparent rigor of quantitative indicators. On the one hand, international numerical comparisons are difficult to refute without knowing the reality of different countries, not usually the case for national policymakers. Also, more generally, numerical estimates create an attractive pseudo-scientific impression that diverts attention from the diverse nature and, especially, the qualitative aspects of what is apparently being measured. It is hardly surprising that estimates are sometimes considered to have almost magical powers. ${ }^{14}$ "Management by numbers" always entails serious risks. In some cases, altering the indicator becomes an end in itself and, since an indicator is inevitably incomplete and imperfect, many of the remedies adopted are little more than window-dressing. This risk increases in developing countries, where it is widely believed that a higher position in the ranking will attract foreign investment. However, since such an improvement does not reflect any real improvement in the institutional environment for firms, the expected foreign investment is unlikely to materialize, possibly resulting in a general lack of confidence in real institutional reform.

Confusion is also prevalent in the field of ideas. Despite the fact that even Hayek (2006, p. 412) considered public registers to form part of the essential nuclear activities in a liberal State, some liberal reformers naively support the reform of formalization processes whose main aim is to dilute any type of control over firms to the extent that the Treasury and other administrative bodies are no longer able to use the registers for fiscal purposes. Such reforms are not only difficult to justify from the tax point of view but in practice are impossible to implement because, as soon as the Treasury suffers from poor information, it creates a new fiscal register, thus duplicating procedures (as shown by the experience in Colombia analyzed in detail in Arruñada, in press).

With regard to vested interests, simplification seems attractive for many reasons. The politicians like it because it gives an impression of modernity and speed, and promises results in

\footnotetext{
14 The comments of the Doing Business team on the Dutch reforms are revealing. After stating that "the most important factor” for the success of the reforms in the Netherlands in 2003 was setting a 25\% target reduction in regulatory costs for businesses, calculated at 16 billion euros, Ladegaard, Djankov and McLiesh recommend that a further 25\% reduction should be set as a target for 2011 (2007, pp. 6 and 8). However, they preferred that, instead of $25 \%$, the new target should be set at $20 \%$ to prevent the public from confusing the new target with the previous one: "There is an issue of whether a second $25 \%$ target may be confusing to citizens and businesses. They may ask 'Didn't you already achieve this?' A different number can be picked, say 20\%, to avoid this confusion. The point here is that the authors believe that a second $25 \%$ target is achievable.” (p. 16, n. 13). In such a situation, why not set a target of $100 \%$ ? That would seem reasonable if it was really true that "none or very few of the 196 measures included in the Dutch reform program to date have required political trade-offs between the gains of burden reductions and the real or perceived reduction in level of regulatory protection” (p. 7).
} 
the short term. They prefer to include this type of action on their political agendas rather than others that are more necessary but have a higher political cost such as the reform of pensions or public health systems. Moreover, such reforms bring with them international recognition. Costly consultancy services are needed to carry out the re-engineering of procedures and install information systems. These services are difficult to evaluate and allow a larger degree of discretion than is required, for example, in the construction of physical infrastructure. Almost all such reforms also make it necessary to take on new personnel, especially when they take the form of a one-stop shop or single access point alongside pre-existing bodies. A new bureaucracy is thus built up, creating new job opportunities that are often better paid than standard opportunities in the local labor market. Finally, such reforms have generated a whole new "profession" whose job it is to simplify procedures but such professionals, being only human, may well succumb to rentseeking, just as their predecessors did before them.

\section{A Manichean view of economic reality}

In the pilot study on the Doing Business project, Djankov et al. expressed the conviction that their empirical results confirm a rent-seeking hypothesis and concluded that politicians and bureaucrats introduce regulations on business formalization for their own benefit and not to serve the public interest. This black and white view of economic reality is wrong because the two hypotheses presented by Djankov et al. as alternatives (rent-seeking and public interest) are neither mutually exclusive nor incompatible. On the one hand, a certain degree of regulation of formalization is in the public interest. And it may be that there is no single optimal degree but rather that this optimum varies from country to country in line with their institutional, demographic and economic characteristics. The fact is that all countries regulate formalization to some extent, and always with substantial elements of compulsion. On the other, it is not only the initial regulation of formalization that suffers from rent-seeking. When, as is usually the case, the incentives for public servants and other agents remain unchanged, it can be assumed that reforms in this field, including reforms announced as liberalizing, also suffer from rent-seeking.

Our argument can be applied across the board — any institution can be assumed to have specialized resources and specialization inevitably leads to rent-seeking, transaction or agency costs, on the part of both the public registers and the professionals involved in the formalization process, be they lawyers, notaries, accountants or even the press. ${ }^{15}$ It is true that there is a large degree of rent-seeking and this should be considered in reforms both to make them viable and to reduce the risk of such rent-seeking increasing in the reformed institutions. But this does not mean that the problem is only one of rent-seeking, nor that rent-seeking is the most important part of the institutional problem, because the institutions carry out useful functions and their efficiency does not only depend on their costs but also on the value of their services. It is not all rent-seeking. This is shown by the fact that, to a greater or lesser extent, all countries regulate formalization. Moreover, rent-seeking does not explain why formalization is regulated in different ways in different countries, nor what is the minimum regulation needed for formalization nor, more generally, how formalization processes can be organized in a more efficient way. To be more

15 This idea has often been expressed in the economic analysis of institutions. See, for example, Barzel (1997, p. 14). 
specific, rent-seeking does not help identify which formalities can be eliminated. On the basis of these arguments and the analysis of the real cases in Arruñada (in press), it could even be considered that the emphasis on rent-seeking is not the right starting-point. Especially because it may lead us to disregard the fact that these institutions should generate value and that reforms should aim to achieve efficiency rather than just the reduction of costs and income. And in many countries, especially less developed ones, such efficiency makes it necessary to enhance the value of institutional services.

\section{A defective method}

On the basis of a survey, Doing Business considers several variables (number, time and cost) relating to the formalities required for starting a business. With the aim of obtaining comparable data, it introduces a number of hypotheses and obtains information using a common procedure for all countries. ${ }^{16}$ As already mentioned, this method creates distortion because it only considers the initial costs involved in time and money. It completely disregards the different benefits that different formalization systems should provide in the future for both private firms and government departments. It disregards, above all, the negative effects of low-quality formalization in terms of future transaction costs and litigation. ${ }^{17}$ Moreover, the method covers only some of the formalities and costs. It considers only the compulsory interactions between entrepreneurs and external agents such as government agencies, lawyers, accountants and notaries, omitting procedures that may not be compulsory but are widespread and hard to avoid. It also assumes that the entrepreneur carries out all the formalities himself, without using any type of intermediary.

Both patterns - focusing on costs and considering only the compulsory formalities - are complementary in the bias they create for measuring the phenomenon. This is because a formalization system may seem cheap if the prices are low and there are few requirements, but public agencies and private entrepreneurs have to make up for its shortcomings by carrying out additional controls and purchasing additional services - public agencies have to set up parallel registers, and entrepreneurs have to employ lawyers to perform extensive legal "due diligence" work prior to rendering an opinion. This greater reliance on lawyers deserves an explanation. When the company register just records companies' documents, and accredits only the date on which such documents are filed, entrepreneurs have to take on more private advisors in order, on the one hand, to ensure they are acting legally and, on the other, to examine the legal quality of the recorded documents of other companies with which they contract, and reduce their information asymmetry with respect to them. In countries where the register is not even reliable for the date of filing (often the case, because of malfunction or corruption), the demand for private services is even greater, although it focuses on providing personal, rather than impersonal,

\footnotetext{
16 See the various annual reports (World Bank, several years) and a description of the methodology in "Starting a Business” http://www.doingbusiness.org/MethodologySurveys/StartingBusiness.aspx (visited 24 August 2007).

17 By measuring only the costs prior to setting up the business, the Doing Business method favors countries which control legality a posteriori using the judicial system, and is detrimental to countries, such as those applying continental Latin-Germanic Civil Law, which are more cautious a priori in the hope of avoiding litigation a posteriori. See Ménard and du Marais (2006) for a critique of Doing Business for its inability to capture the specificities of legal systems.
} 
assurances for credit and business transactions. Moreover, by disregarding all these formally voluntary services, the comparison between the different systems is greatly distorted, especially for a firm of the size taken by Doing Business as the benchmark, ${ }^{18}$ this being the size for which the complexity of formalization in most countries in fact requires entrepreneurs to take on not one but several advisors.

In more general terms, the emphasis placed by Doing Business on the costs of compulsory formalities omits two types of substitution: firstly, the substitution that takes place initially between the costs of compulsory procedures and those of voluntary procedures; and, secondly, the substitution that takes place between the costs of initial procedures and future procedures.

The former substitution - that between compulsory and voluntary services - takes place because, if registers carry out minimal control, the costs will be low but the parties will have to take on additional services to achieve an acceptable level of legal certainty. Given the difficulties of quantifying the costs of due diligence on corporate matters in a cross-section of countries, I will present two examples from property formalization, linked more directly to the "Registering property" indicator in Doing Business (0). They reveal that the operating costs of banks for mortgage loans are higher in European countries with deed recording, which only record contracts without checking their legal validity, than in those with registers of rights, which do check legal validity. ${ }^{19}$ Registers of rights could therefore be expected to incur higher costs for formalizing transactions. ${ }^{20}$ And the same could be expected for the costs of lawyers and notaries, although these services are compulsory in most countries.

The second type of substitution - between initial and future costs - can also be seen in 0 , which shows that the periods for foreclosing a mortgage (and therefore its costs) are much shorter in countries with registers of rights (see also Figure 1). This is because registers of rights are in a position to certify current rights and priorities, facilitating calculation of the debt, reliably

18 The firm taken by Doing Business as a benchmark is a limited liability company with articles of association ten pages long, with five national individual partners providing start-up capital in an amount equivalent to ten times the national income per head. The company rents its premises and does not enjoy tax privileges, has up to 50 employees and operates in the country's most populous city, in a sector without any special regulation. Moreover, it records sales of at least 100 times income per head. (See for details the methodology referred to in $n$. 16). A related question is for what purpose and country it is ideal to consider the formalization of a company of this size. It seems reasonable to assume that for developing (although also for developed) countries, the greatest barriers are those faced by the smallest firms, including individual entrepreneurs, because many of the costs of formalization are fixed so have a greater impact on smaller businesses.

19 According to a report drawn up by Mercer Oliver Wyman for the European Mortgage Federation "operating cost (defined as distribution, origination and servicing costs only) as a proportion of outstanding lending varies considerably across countries. This analysis suggests that the countries studied fall into two broad categories: Those with relatively higher operating costs as a proportion of outstandings (Italy, France and Portugal). The main drivers of this appear to be more complex legal processes (particularly Italy) and low average loan sizes which lead to higher cost as a proportion of loan size. Countries with relatively lower operating costs as a percentage of outstandings (Denmark, Germany, Netherlands, Spain and UK). We note that these countries have both higher average loan sizes but also have more efficient mortgage processes such as mortgage registration and repossession. While the cost estimates must be interpreted with caution, they are broadly supported by qualitative evidence provided by lenders in each country" (2003, pp. 43-44, emphasis added).

${ }^{20}$ In fact, the costs are not necessarily higher, as shown by the situation of real estate registers in Europe, in which deed recording is seen to have much higher costs than registers of rights (EMF, 2006, as analyzed by Arruñada, 2007a). 
establishing the priority of the different mortgages and avoiding possible litigation on ownership, proxies and the legal capacity of the contracting parties. In other words, the insolvent debtor has a small, closed number of defenses available. But this is only possible when, before registration, the register of rights has already fully checked the legal validity of every transaction involved.

So the main defect in the method used in Doing Business is that it only estimates the compulsory initial costs. These may be informative but they provide a weak base for reform of the formalization system because of the important substitutions existing between costs for compulsory and voluntary services and between initial and future costs. It therefore seems necessary to consider the matter in terms of standard costs as well as future costs which, to a large extent, are inversely related to the value of the services being provided by the formalization institutions. Only in this way can we achieve an idea of the efficiency of the institutions and the different ways in which they are organized.

This, however, should not be understood as an endorsement of formalization systems with a particular mix of ex ante and ex post services or, in particular, as an endorsement of "registration" systems with heavier ex ante control than systems for mere "recording" or "notice". The point here is a simple warning that, when measuring the efficiency of legal and, especially, of formalization institutions, we should consider costs incurred and benefits obtained both ex ante and ex post. The tradeoffs of such systems have been discussed elsewhere. ${ }^{21}$

\section{An inappropriate method}

The emphasis on costs leads Doing Business not only to neglect the need for the formalization systems to provide valuable services but also the fact that in every country the best solution (regarding both technology and the optimum average cost) will depend on the demand for formalization services, this being a social demand that helps define their value. There are two aspects to this social demand-quality and quantity.

\subsection{Demand: quality and quantity}

The demand for services may vary in terms of quality. Essentially, formalization can be seen as a procedure for defining a set of property and decision rights with a certain degree of precision. The pioneering argument drawn up by Demsetz (1967) is applicable here. It states that economic agents demand greater precision in the definition of rights for the most valuable assets or, in dynamic terms, as the assets increase in value. This argument can be applied in the field of business formalization, adapting the model designed by Arruñada and Garoupa (2005) for property rights in land. In such a model, the value of property rights depends on the probability that claimants with better legal rights might appear. The three legal systems we consideredprivacy, and the two public systems of recording of deeds and registers of rights-increasingly reduce this probability but involve proportionately higher costs.

21 Mainly Arruñada and Garoupa (2005) and Arruñada (2007b, Ch. 5). 
For business firm formalization, the given value of a firm's assets changes, ceteris paribus, in that their use for production entails transaction costs, which vary depending on whether the firm has been formalized or not, and according to which system. This is similar to property rights in land. First, a system of privacy is similar to business informality, without any public control ex ante. Second, the types and effects of land registers parallel those of company registers: land recording resembles a notice system in which companies simply file their documents in a public office, while land registration corresponds to company registration systems in which, in addition, the legality of the documents filed is checked by a public official, resulting in more powerful legal effects. The actual cost of business formalization also varies across formalization systems, with higher costs to be expected under a registration than a notice system.

Under these conditions, each entrepreneur will choose the degree of formalization that maximizes the value of the firm and, from the social point of view, the optimum formalization system depends on the costs and value of the different systems and on how the value of firms is distributed throughout the economy. Figure 2 shows that an entrepreneur's individual decision will be to remain informal for low firm values, whereas social decisions as to whether or not to set up a formalization system and, if so, which one, will depend not only on the formalization costs and the greater value resulting from the reductions in future transaction costs offered by each system, but also on how the value of firms is distributed in each economy. If we apply the conclusions reached in Arruñada and Garoupa (2005), when a formalization system exists, entrepreneurs will decide whether or not to formalize depending on the value of their firms. As a result, the social choice as to which is the most appropriate legal system is determined by the net balance of three effects. A formalization system with little ex ante control by a public agency (a recording or notice system) raises the transaction costs of large firms (under-assurance), and a formalization system with heavier ex ante public control of legality (closer to registration) leads to a situation in which small firms remain informal (crowding out) or excessively reduce their transaction costs (over-assurance). In a similar way to what happens with real property, the net balance of such effects and, therefore, the optimum system are determined by the distribution of firms and the effectiveness and relative costs of the different systems, including those of the private assurance services that may act as complements or substitutes of the public formalization system. Optimal policy decisions will, therefore, require substantial adaptation to local circumstances.

Not only the quality of services required but also their quantity may distort valuations based on total average costs as a result of economies of scale both nationally and within each formalization office. The attached figures illustrate the two possibilities. Firstly, Figure 3 shows that, according to Doing Business data, the average costs of registering a company are higher in less developed countries. Secondly, Figure 4 illustrates the economies of scale enjoyed by formalization offices, based on data from Spanish land registers. Doing Business and similar studies measure only the vertical axis which represents the average cost. Then, after comparing it across countries, conclude that the countries with the lowest average costs have the most efficient institutions. But the institutions in countries having different levels of development and therefore different levels of demand for formalization can be expected to have different optimum average costs. In fact, a higher average cost in a country whose system functions at a lower scale does not necessarily indicate that its system is less efficient. Its institutions may be functioning efficiently, at precisely the frontier of productive possibilities, but at a lower scale and perhaps with different technology. And vice versa, a richer country may show lower average costs only as a result of the 
scale, even though its system is inefficient. Therefore, the comparison of average costs cannot in itself resolve these doubts.

By emphasizing the reduction of unit average costs, Doing Business falls in the same old trap as some managerial accounting systems, which led firms to choose capital-intensive technologies and to produce excessively large batches of products (Jensen and Meckling, 1998). In the case under discussion here, capital-intensive technologies are also favored as they offer lower variable average costs and it is often the case that only the variable costs are estimated. Doing Business, for instance, only estimates the costs paid by users, but not the fixed costs of creating and starting up formalization systems which, in the case of the reforms that Doing Business advocates, are usually covered by the governments or by development aid agencies. Since, moreover, demand (that is, the value of the services) is not considered at any time by Doing Business, the reforms adopted are often not the most appropriate for the country in question.

\subsection{Formalization in Peru}

An example from the real estate sector reveals how inappropriate this type of reform can be. Peru has spent hugely in formalizing real estate property-over 214 million dollars between 1991 and 2002 alone, financed with loans from the World Bank since 1998. ${ }^{22}$ But a large proportion of the formalized properties leave the formal system when the land is sold again and very few mortgages have been registered, in spite of many years of subsidized prices for registration.

A report drawn up for the promoters of the reform points to the decisive fact that "it is not clear that beneficiaries place greater value on a registered title than on other ownership documents, such as municipal certificates or sale and purchase contracts, which have not necessarily been purged and registered". The report considers, rather naively, that "to some extent this can be explained by the widespread culture of informality amongst the population and also by the lack of knowledge of the benefits of having a registered title”. According to the report, this ignorance is also behind the fact that "a large percentage of the formalized population does not place any additional value on the fact that their ownership title has been properly purged and registered". In order to resolve this, the body in charge of formalization (Cofopri) is carrying out an extensive information campaign with the aim of "preventing the great effort at formalization from being wasted because a register that is not updated is of little use and everything seems to indicate that, once the Cofopri title has been registered, a large proportion of the beneficiaries have not registered second transactions" (Morris Guerinoni, 2004, pp. 20-21, emphasis added). On this basis, one may well think that the so-called "ignorance" may be just imaginary, and the fact that owners do not register sales may be due, rather, to the limited additional value of the titling granted by the system to the properties in question.

Moreover, with regard to credit, the results of the experience have apparently been zero because "no important differences are noted for each type of title certificate, except for a slightly higher degree of approval of Cofopri applications (96\%).... [nor] a higher use of the ownership title in access to credit, because this seems to be linked more to the applicant's payment capacity

\footnotetext{
22 ILD (2007, p. 65). In 2006, the World Bank granted an additional loan of 25 million dollars, subsequent to a previous one of 38 million that ended in 2004 (Cofropi al día, 28 November 2006, http://www.cofopri.gob.pe/noticias_banner/banner_asp.asp?codigo=172, visited 7 March 2007, p. 1).
} 
than to the holding of guarantees for the financial institution. The results show that the probability of approval of applications for loans is similar for those having a Cofopri title and for those having no ownership document as the two groups gained access to formal sources in the same proportion. With regard to financing systems, there were no marked differences” (Morris Guerinoni, 2004, pp. 23-24). What did increase slowly was the number of mortgages registered (between 4.18 and 5.59\%, a tiny percentage considering that by the end of 2003 76,272 mortgages had been registered out of a total of 1,824,087 formalized entries for which 1,364,434 titles were granted [pp. 98-99]). Moreover, practically nothing is known about the characteristics of these mortgages such as their effects on the cost of the credit (especially the proportion between the value of the credit and the value of the property and the difference in the interest rate in comparison with a loan with no real guarantee). Therefore, it is unknown whether their role is to act as a credit catalyst or just as an insignificant complement to guarantee payment. ${ }^{23}$

These failures in second transactions and mortgages have been blamed on the rising prices of notarial intervention (ILD, 2007). It is true that notaries do make formalization more expensive but the problems with second transactions and mortgages arose prior to the successive reintroduction of notarial privileges in 2002 and 2004. From the notarial point of view, it has been argued that informal owners value de facto possession more than formal ownership (Webb, Beuermann and Revilla, 2006). This argument has the virtue of relativizing the value of legal certainty provided by an universal formalization system but it ignores the fact that the market faces many difficulties when titles are informal. Standardization is needed for transactions to be possible at low cost between parties who do not know each other. Survey data says, for example, that 44 percent of people with no legal document feel secure about their property whereas, for those who have all the appropriate documents, the figure is $92 \%$. But what matters is not so much how secure the actual possessors of the property feel but rather how potential purchasers or mortgage creditors would feel and, more importantly for our argument, what is the real demand for such security for third parties.

In general, the negative results of these ambitious projects for universal titling are only to be expected considering that they do not often meet a real demand linked to asset value and investment opportunities. This is made clear by the experience of the more developed countries which have tended to be extremely slow in registering property, taking decades, or even centuries, once they started organizing their systems in the $19^{\text {th }}$ century. ${ }^{24}$

\footnotetext{
23 Positive effects on investment and on the supply of labor have been claimed by Field (2004, 2005, 2006), as titling supposedly allows squatters not to rely exclusively on physical possession to enforce their rights. However, endogeneity cannot be discarded from her data. In addition, the effect on labor is hard to reconcile with the closelyknit nature of many communities of squatters.

24 Some historic examples are given in Arruñada (2003, especially pp. 401-44). For example, registration of rights was introduced in England and Wales gradually and following geographic criteria, starting with the city of London in 1897. Coverage only reached a majority of properties in the last few decades of the $20^{\text {th }}$ century.
} 


\section{A wrongly-applied method}

In addition to its structural weaknesses, the actual application of the Doing Business methodology also seems to be plagued by measurement errors, and not only in developing countries as might be expected. The following example from the United States illustrates these problems.

Taking New York City as its reference, Doing Business reports for the US that registering for sales tax can be done on-line and takes only one day. ${ }^{25}$ Firms can apply on-line, true, but in New York State they have to apply at least 20 days before they start operations. Otherwise they face heavy penalties, according to the New York State Department of Taxation and Finance. ${ }^{26}$ Moreover, Doing Business seems to suggest that payment of sales tax is exceptional because it states that "businesses selling 'tangible personal property (goods), as well as certain other goods and types of services' are required to be registered as a Sales Tax Vendor”. But such registration is not at all exceptional, as shown by the list drawn up by the NYSDTF, and includes practically all types of economic activity (2004a, pp. 17-19).

Similarly, another mandatory formality, that of purchasing private insurance coverage is not as easy in NYC as Doing Business 2005 assumes (it also gives one day). First, it requires obtaining the Unemployment Insurance Employer's Registration Number (UIER), after faxing or mailing the NY State Department of Labor and, supposedly, receiving it by similar means, hardly a oneday procedure. ${ }^{27}$ And obtaining private insurance is not exactly easy if we take into account the information provided by the New York State Workers' Compensation Board which, amongst other things, recommends that firms should request quotes from several insurance carriers "several months before you need the policy". ${ }^{28}$ Furthermore, at least one additional day should be

\footnotetext{
25 See the details on the US in http://www.doingbusiness.org/ExploreTopics/StartingBusiness/Details.aspx?economyid=197 (visited 24 August 2007).

26 A guide for entrepreneurs reads as follows: "If your business is required to be registered as a vendor, it must obtain a Certificate of Authority from the Tax Department. This certificate gives your business the authority to collect the required sales and use taxes, and to issue appropriate sales tax exemption documents, including resale certificates used for purchasing inventory. If your business makes taxable sales before it receives the Certificate of Authority, it may be subject to substantial penalties. To obtain a Certificate of Authority, you must complete Form DTF-17, Application for Registration as a Sales Tax Vendor, for your business and send it to the address listed in the instructions for that form, at least 20 days before you begin operating your business" (NYSDTF, 2004b, p. 19, emphasis added). Updated versions of this guide use similar terms. See, e.g., pp. 15 and 30 of the October 2007 version, available at http://www.tax.state.ny.us/pdf/publications/multi/pub20_1007.pdf (visited October 26 2007).

27 See detailed information on the New York State Department of Labor website (http://www.labor.state.ny.us/ui/dande/register1.shtm, visited 21 February 2007).

28 The New York State Workers' Compensation Board makes the following recommendation: “Generally, private insurance is purchased through a broker or agent. Different insurance carriers cater to different markets and offer different incentives to policy holders. It is important for an employer to 'shop around' to make sure that they are buying the coverage that is best for them. Some insurance carriers may choose to not write insurance for a particular industry or size of employer. If an employer finds themselves in this situation, they should contact their agent and ask them to look around for other coverage. The costs can and do vary between insurance carriers due to discounts, dividends and incentive programs". It also gives advice on obtaining the right coverage: "Workers' Compensation insurance can be an expensive cost of doing business. However employers can take responsibility for those costs by
} 
added to follow the actual Doing Business methodology, which assumes any procedure takes at least one day. 29

Considering the real duration of these formalities would radically change the position of the United States in the Doing Business ranking. If we were to duly apply the Doing Business method, we would have to consider at least the 20 days needed for sales tax registration and the additional day needed, at least, for taking out the labor insurance. This would take the period for starting business in the US from 5 to 26 days, bringing the country down in the ranking from positions 3-5 at which it was rated by Doing Business 2007, alongside Denmark and Iceland, to positions 57-60, alongside El Salvador, Lithuania and Sierra Leone. ${ }^{30}$

\section{The need for a value strategy}

While they are serious, these failures in measuring and applying the method, are of relatively little importance. If Doing Business is generating incorrect policies, these result, not so much from imprecise measurement but from the incorrect theoretical and methodological approaches adopted. Doing Business is generating errors mainly because it disregards the value of the services in question, placing the emphasis on their cost, thus promoting sterile reforms while speeding up useless formalities.

The incipient efforts being made by some developed countries to include administrative simplification in a larger effort to improve quality of regulation are just a small, first step in the right direction (for example, OECD, 2006, p. 100). This is because quality of regulation as a concept is insufficient for the activities of public bodies (such as company and property registers) in which the Administration not only regulates but also provides services which, in turn, are used as an input in other public activities (especially the judiciary) and private activities (business transactions). For both activities, it is essential, when evaluating quality of regulation, to explicitly consider the value and quality of the services involved.

What it is needed, in particular, in business formalization are policies that not only simplify formalities or improve the quality of regulation but also increase the value of the information provided by public registers to their users, both public and private. This is because business formalization - their recording in the different public registers-is an ordinary productive process that incurs costs but also provides valuable public and private services. The private services

following some of the tips below: [1] Start getting quotes from a variety of insurance carriers through your agent. Do this several months before you need the policy. [2] Make sure that the underwriter is using the proper classification of employees. If you are misclassified to get an initial lower rate, an audit will catch this and you will be charged retroactively. [3] Discuss what types of alternative plans are available (deductibles, premium credits, safety programs). [4] Research the insurer's claims handling practices. A carrier that either automatically pays every claim or controverts many claims can directly affect your premium in the future”. (NYSWCB, 2004, pp. 14 and 16).

29 The fact that one day is considered for each procedure, even though they could in fact take place simultaneously and in less time, goes against the countries that have more complex systems or have given more detailed information, lowering their positions in the ranking.

30 According to data offered on-line by Doing Business on 25 February 2007 (http://www.doingbusiness.org/ExploreTopics/StartingBusiness/). 
reduce firms' transaction costs in many of their contracts, and the public services facilitate the work of the Administration in its dealings with firms.

Even though many of these services are indispensable for transactions between strangers and companies, most simplification reforms focus narrowly on reducing a single part of the costs, namely, those paid directly by firms when they formalize their activity, disregarding both the costs of public agencies and, most importantly, the need to increase the value of the services provided, which is currently nil in many developing countries. This is especially serious considering that, in such cases, if one had to choose or establish priorities between reducing costs or increasing the value of formalization, one would prefer to increase the value because reliable registration services are an essential catalyst for all economic activity, in particular for impersonal transactions, with strangers and other firms.

This emphasis on value is needed because registration information can only reduce transaction costs when the judiciary considers it trustworthy, so both the entry and exit of data in and out of the register must be fully reliable. The degree of control of data inputs may vary but the register must be reliable in all the aspects on which it has to inform (at least, on the date of filing and the content of the filed documents), if it is to have any legal effects, and such legal effects are indispensable for reducing transaction costs in the future, thus underpinning impersonal business relations. If the register provides unreliable information, the judges will disregard it and the economic agents will reject it, making business contracts more expensive or impossible, as they will have to be based exclusively on personal relations amongst entrepreneurs.

Moreover, registers and other entities serving as one-stop shops must be reliable if the simplification of formalities is to be real and lasting. To be real, they must be the only such entity and must transfer information to the tax and other authorities without the need for entrepreneurs to apply to several registers. To be lasting, the information must be sufficiently well-controlled to meet the needs of the tax and other authorities that are responsible for administrative records. In other words, only if a company register is reliable can it carry out the supervisory tasks required for other government registers, especially tax registers. This reliability is therefore essential if the efforts to unify formalization processes through one-stop shops, speeding up procedures, are to achieve the desired results. If registers are unreliable, administrative registers will subsist making it impossible to eliminate procedures or, if simplification is achieved, it will be short-lived because such administrative registers and the procedures they entail will tend to be re-established as soon as the bodies involved note that the one-stop shop system does not provide the degree of control needed for efficient functioning.

In view of the legal value of registration information, if reforms of formalization processes are to be useful, we have to consider all the users, both direct and indirect, that is, not only the firms carrying out formalization but also the judiciary and the public administration. By considering judges as users, focus will be placed on the main value provided to businesses by effective formalization, which is to lower future transaction costs by reducing the information asymmetry suffered by contractual partners. By considering the public administrations as users, it will be possible to simplify public registers in a sustainable way, avoiding the duplication that exists today between commercial, tax and administrative registers.

For the same reason, the opinion of judges and administrative users should receive special consideration when evaluating and supervising reforms. Positive evaluations made by entrepreneurs regarding the speed or functioning of formalization systems should be treated with 
caution as they are often based on partial views and do not take into account the effects of the reforms on register reliability , the quality of register outcomes and their impact on future transaction costs of firms.

In summary, the main priority should not be to reduce the cost of business formalization-a cost paid only once-but rather to reduce transaction costs in all business dealings. The latter are recurring costs representing much larger amounts although most of them are invisible opportunity costs because they stem from exchanges that have become impossible. The re-structuring of formalities is in itself insufficient for reducing total transaction costs. It may also be a costly distraction. It is necessary, rather, to enhance the value of formalization.

\section{References}

Arruñada, Benito, 2003. Property Enforcement as Organized Consent. Journal of Law, Economics, \& Organization 19(2), 401-444.

Arruñada, Benito, 2007. Market and Institutional Determinants in the Regulation of Conveyancers. European Journal of Law and Economics 23(2), 93-116.

Arruñada, Benito, in press. Formalización de empresas: Costes frente a eficiencia institucional, Thomson, Cizur Menor.

Arruñada, Benito, and Nuno Garoupa, 2005. The Choice of Titling System in Land. Journal of Law and Economics 48(2), 709-727.

Barzel, Yoram, 1997. Economic Analysis of Property Rights ( $2^{\text {nd }}$ ed.). Cambridge Univ. Press, Cambridge and New York.

Butler, Stephen B., 2003. Enforcement of Mortgage Rights in Housing Finance. In: Housing

Finance in Emerging Markets: Policy and Regulatory Challenges. The World Bank, Washington DC, 10-13 March.

de Soto, Hernando, 1986. El otro sendero: la revolución informal. El Barranco, Lima.

de Soto, Hernando, 2000. The Mystery of Capital: Why Capitalism Triumphs in the West and Fails Everywhere Else. Basic Books, New York.

Demsetz, Harold, 1967. Towards a Theory of Property Rights. American Economic Review 57(2), 347-359.

Djankov, Simeon, Rafael La Porta, Florencio Lopez-de-Silanes and Andrei Shleifer, 2002. The Regulation of Entry. Quarterly Journal of Economics 117(1), 1-37.

EMF, European Mortgage Federation, 2002. Efficiency of Mortgage Collateral in the European Union. EMF, Brussels.

EMF, European Mortgage Federation, 2006. Study on the Cost of Housing in Europe. EMF, Brussels.

Field, Erica, 2004. Property Rights, Community Public Goods and Household Time Allocation in Urban Squatter Communities. William and Mary Law Review 45(3), 837-887. 
Field, Erica, 2005. Property Rights and Investment in Urban Slums. Journal of the European Economic Association Papers and Proceedings 3(2-3), 279-290.

Field, Erica, 2006. Entitled to Work: Urban Property Rights and Labor Supply in Peru. Harvard University (available at http://post.economics.harvard.edu/faculty/field/papers/Field_COFOPRI.pdf, visited 17 June 2007).

Hayek, Friedrich A. von. 1979. Law, Legislation, and Liberty. Routledge \& Kegan Paul, London. (Spanish translation used here: Derecho, legislación y libertad. Unión Editorial, Madrid, 2006).

ILD, Instituto Libertad y Democracia, 2007. La guerra de los notarios. ILD, Lima (available at http://www.ild.org.pe/download.php, visited 7 March 2007).

Jensen, Michael C., and William H. Meckling, 1998. Divisional Performance Measurement. In: M. Jensen, Foundations of Organizational Strategy. Harvard Business Press, Cambridge, MA, 345-361.

Ladegaard, Peter, Simeon Djankov and Caralee McLiesh, 2007. Review of the Dutch Administrative Burden Reduction Programme. World Bank Group, February (available at http://www.doingbusiness.org/documents/DBdutch_admin_report.pdf, visited 29 March 2007).

MCC, Millennium Challenge Corporation, 2005. Report on the Criteria and Methodology for Determining the Eligibility of Candidate Countries for Millennium Challenge Account Assistance in FY 2006. Washington DC.

Ménard, Claude, and Bertrand du Marais, 2006. Can We Rank Legal Systems According to Their Economic Efficiency? In: Peter Nobel and Marina Gets (Eds.), New Frontiers of Law and Economics. Zürich, Schulthess, pp. 7-27.

Mercer Oliver Wyman, 2003. Study on the Financial Integration of European Mortgage Markets. (Authors: Simon Low, Matthew Sebag-Montefiore and Achim Dübel). European Mortgage Federation, Brussels.

Morris Guerinoni, Felipe (with the collaboration of Víctor Endo D. and Rafael Ugaz), 2004. La Formalización de la Propiedad en el Perú: Desvelando el Misterio. COFOPRI, Lima (available at http://www.cofopri.gob.pe/bdigital.asp?i=3, visited 4 March 2007).

NYSDTF, New York State Department of Taxation and Finance, 2004a. A Guide to Sales Tax in New York State. Publication 750, August (available at http://www.tax.state.ny.us/pdf/publications/sales/pub750_804.pdf, visited 21 February 2007).

NYSDTF, New York State Department of Taxation and Finance, 2004b. New York State Tax Guide for New Businesses. Publication 20, October (available at http://www.tax.state.ny.us/pdf/publications/multi/pub20_1004.pdf, visited 21 February 2007). 
NYSWCB, New York State Workers’ Compensation Board, 2004. Employers' Handbook: A Guide to the Workers' Compensation System for the New York State Business Owner. EH-1 (07/04), (available at http://www.wcb.state.ny.us/content/main/Small_Business/employer_handbook.pdf, visited 21 February 2007).

O’Grady, Mary Anastasia, 2006. Americas: Doing Business in Latin America. The Wall Street Journal 15 September, A.13.

OCDE, Organization for Economic Co-Operation and Development, 2006. Cutting Red Tape: National Strategies for Administrative Simplification. OECD, Paris.

OCDE, Organization for Economic Co-Operation and Development, 2003. From Red Tape to Smart Tape: Administrative Simplification in OECD Countries. OECD, Paris.

Webb, Richard, Diether Beuermann and Carla Revilla, 2006. La construcción del Derecho de Propiedad: El caso de los asentamientos humanos en el Perú. Colegio de Notarios de Lima, Lima.

World Bank, 2003. Doing Business in 2004: Understanding Regulation. World Bank and Oxford University Press, Washington DC.

World Bank, 2004. Doing Business in 2005: Removing Obstacles to Growth. World Bank and Oxford University Press, Washington DC.

World Bank, 2005. Doing Business in 2006: Creating Jobs. World Bank and Oxford University Press, Washington DC.

World Bank, 2006. Doing Business 2007: How to Reform. World Bank and Oxford University Press, Washington DC.

World Bank, 2007. Doing Business 2008. World Bank Publications, Washington DC. 
Table 1. Some basic characteristics of transactions costs in European mortgage markets

\begin{tabular}{|c|c|c|c|c|c|c|}
\hline & $\begin{array}{c}\text { Solicitors' / } \\
\text { notary's } \\
\text { fees }\end{array}$ & $\begin{array}{c}\text { Property } \\
\text { and mortgage } \\
\text { registration }\end{array}$ & $\begin{array}{l}\text { Total legal } \\
\text { costs (lawyers, } \\
\text { notary and } \\
\text { register) }\end{array}$ & $\begin{array}{l}\text { Time needed } \\
\text { for arranging } \\
\text { and registering } \\
\text { a mortgage } \\
\text { (average } \\
\text { days) }\end{array}$ & $\begin{array}{c}\text { Operating cost } \\
\text { of the mortgage } \\
\text { loan for credit } \\
\text { entities (\% of } \\
\text { the mortgage } \\
\text { loan) }\end{array}$ & $\begin{array}{l}\text { Period for } \\
\text { foreclosing a } \\
\text { mortgage, from } \\
\text { debtor insol- } \\
\text { vency (average } \\
\text { months) }\end{array}$ \\
\hline \multicolumn{7}{|c|}{$\begin{array}{l}\text { Countries with } \\
\text { registration of rights: }\end{array}$} \\
\hline $\begin{array}{l}\text { Denmark } \\
\text { Germany } \\
\text { Spain } \\
\text { England }\end{array}$ & $\begin{array}{l}0.6 \% \\
0.7 \% \\
0.8 \% \\
0.4 \% \\
\end{array}$ & $\begin{array}{l}0.2 \% \\
0.3 \% \\
0.2 \% \\
0.1 \% \\
\end{array}$ & $\begin{array}{l}0.8 \% \\
1.0 \% \\
1.0 \% \\
0.5 \% \\
\end{array}$ & $\begin{array}{r}3.0 \\
13.5 \\
8.1 \\
25.5 \\
\end{array}$ & $\begin{array}{l}0.35 \% \\
0.43 \% \\
0.38 \% \\
0.40 \% \\
\end{array}$ & $\begin{array}{r}6 \\
15 \\
8 \\
15 \\
\end{array}$ \\
\hline Average & $0.6 \%$ & $0.2 \%$ & $0.8 \%$ & 12.5 & $0.39 \%$ & 11 \\
\hline \multicolumn{7}{|c|}{$\begin{array}{l}\text { Countries with } \\
\text { recording of deeds: }\end{array}$} \\
\hline $\begin{array}{l}\text { France } \\
\text { Italy } \\
\text { Netherlands } \\
\text { Portugal }\end{array}$ & $\begin{array}{r}2.1 \% \\
4.0 \% \\
\text { n.a. } \\
\text { n.a. }\end{array}$ & $\begin{array}{r}0.2 \% \\
3.3 \% \\
\text { n.a. } \\
\text { n.a. }\end{array}$ & $\begin{array}{r}2.3 \% \\
7.3 \% \\
\text { n.a. } \\
\text { n.a. }\end{array}$ & $\begin{array}{r}30.0 \\
34.5 \\
7.5 \\
37.5 \\
\end{array}$ & $\begin{array}{l}0.68 \% \\
0.72 \% \\
0.45 \% \\
0.50 \% \\
\end{array}$ & $\begin{array}{r}15 \\
60 \\
5 \\
20 \\
\end{array}$ \\
\hline Average & $3.1 \%$ & $1.8 \%$ & $4.8 \%$ & 27.4 & $0.59 \%$ & 25 \\
\hline
\end{tabular}

Sources of data: EMF (2006), for the first three columns, and Mercer Oliver Wyman (2003) for the last three. 
Figure 1. Period for foreclosing a mortgage in line with intensity of formalization

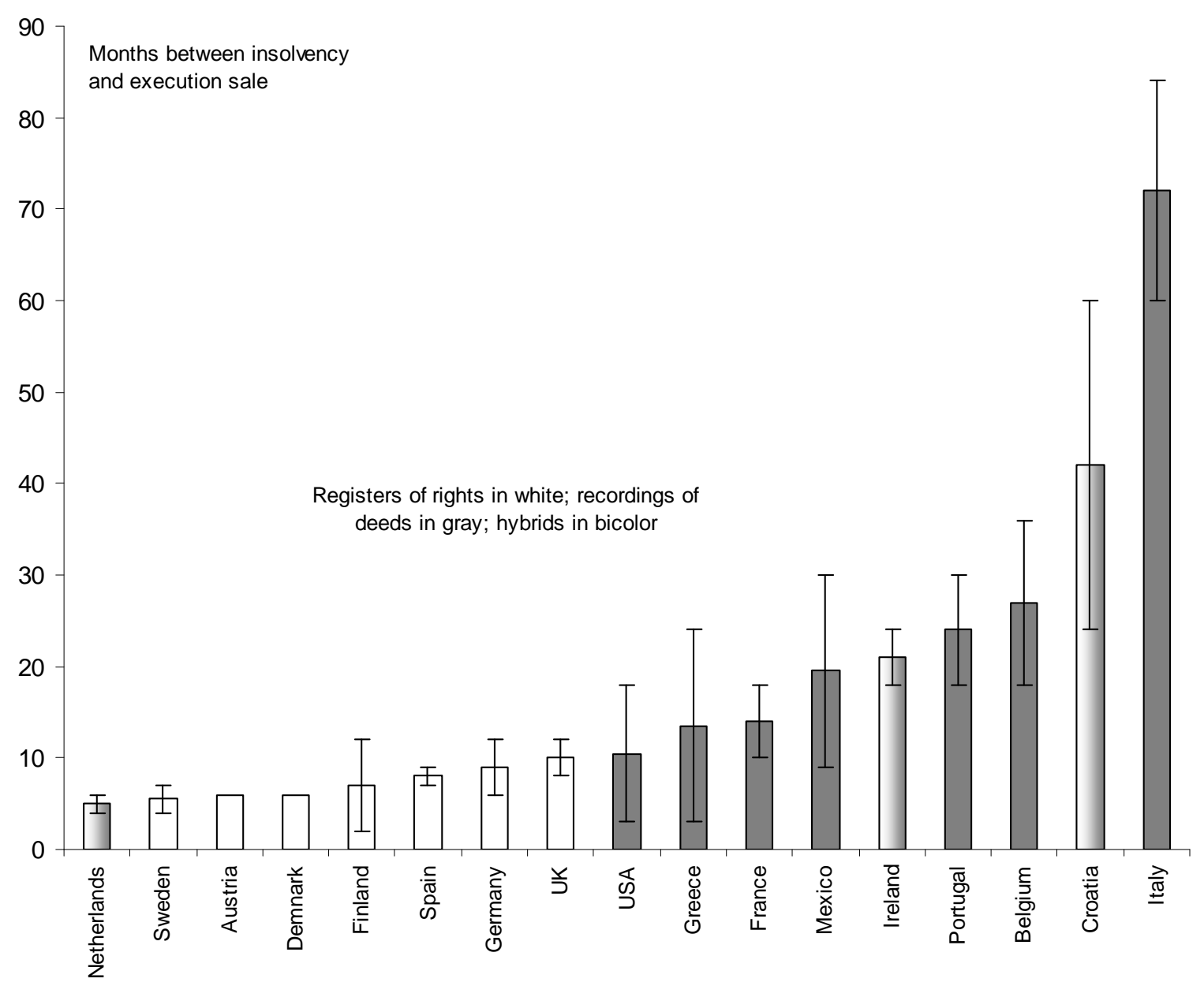

Note: The segments indicate the range of estimated variation in the foreclosing period. Sources of data: EMF (1002) and Butler (2003). 
Figure 2. Firm value in terms of the institutions available for formalization and the entrepreneur's decision

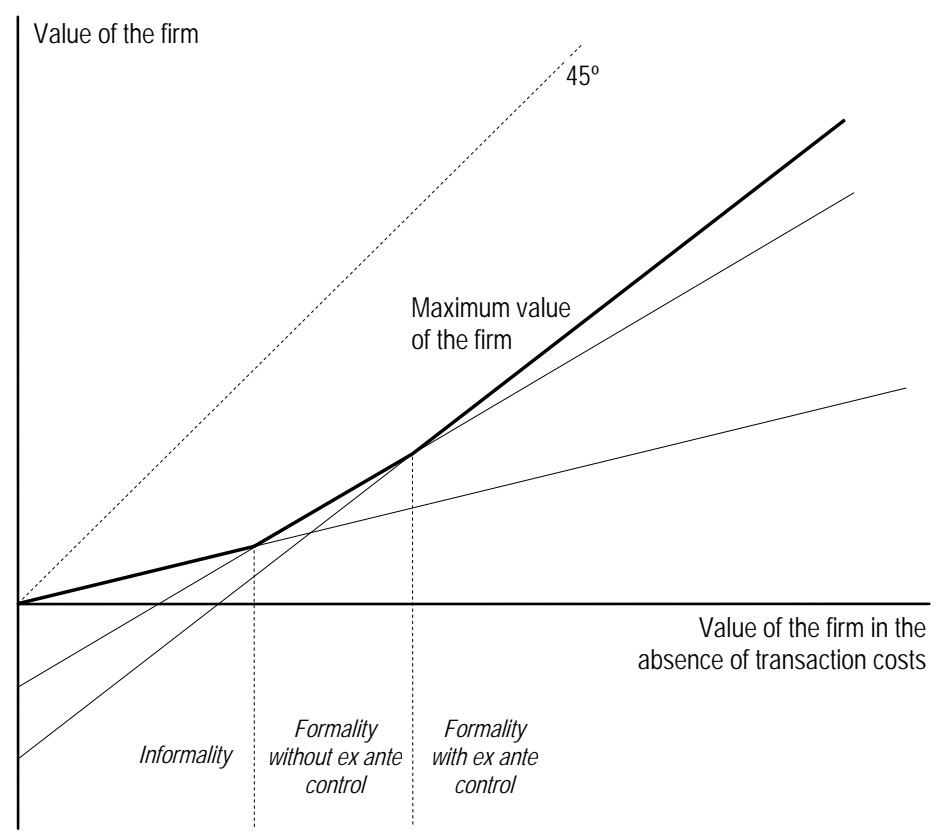

Source: Adaptation to business formalization of Figures 1 and 2 in Arruñada and Garoupa (2005). The value of individual firms is a function of transaction costs and these depend on the type of formalization institutions, which incur different fixed and variable costs. Social choice of formalization institutions depends on these costs and the distribution of firms in the economy. 
Figure 3. Income per head (in US\$) and cost of formalization (in \% of income per head)

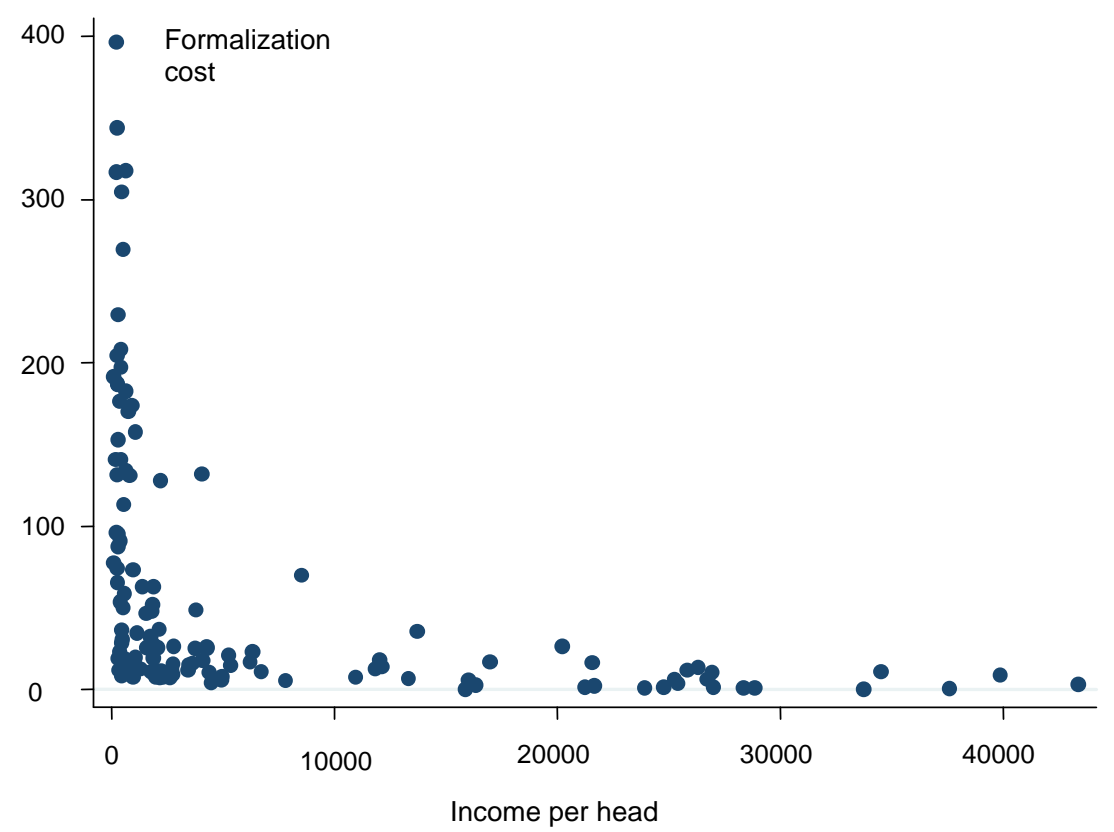

Source: Drawn up by the author based on data from Doing Business 2005. 
Figure 4. Indicator of the average cost of Spanish land registries in terms of their degree of activity, measured by the number of annual entries (1998)

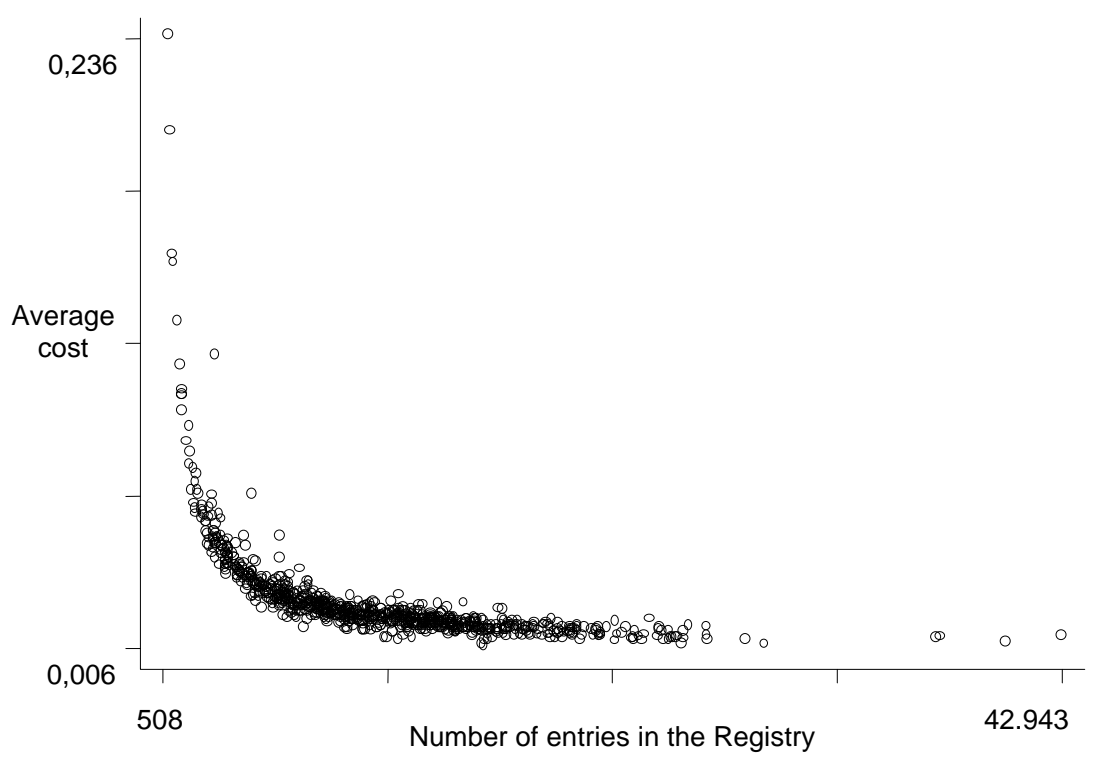

Source: Based on data from the Anuario de la Dirección General de los Registros y del Notariado (Yearbook, Spanish General Department for Registers and Notaries, 1998). 